\title{
Variability in sub-regional impacts of dwarf mistletoe on mature lodgepole pine
}

\author{
by Alan J. Thomson ${ }^{1}$, John A. Muir ${ }^{2}$ and Kathy J. Lewis ${ }^{3}$
}

Impact of lodgepole pine dwarf mistletoe was determined in six sub-areas of Forest Inventory Zone H, near Prince George, British Columbia, using a roadside survey and measurements of mature infected trees. Mistletoe effects on DBH were evident only in two of the sub-areas surveyed (Westlake and Nechako). After correcting DBH measurements for competition (stand density), dbh of $100-120$ year old and $121-150$ year old trees was reduced $10 \%$ and $17 \%$ respectively, in the highest mistletoe rating (DMR) category (4.5-6.0). Height/DBH relationships were affected by dwarf mistletoe only in the Nechako area. Mistletoe effects in the Nechako and Westlake areas, in stands older than 120 years with mistletoe ratings of 4.5-6.0, resulted in volume reductions of $28-42 \%$, depending on the effects of mistletoe on height. Further losses might accrue in lodgepole pine stands if clear-cut harvesting were restricted by the BC Forest Practices Code, unless infected stems are selectively removed.

Key words: roadside survey, dwarf mistletoe rating (DMR), Forest Practices Code
L'impact du faux-gui sur le pin lodgepole a été déterminé dans six sous-régions de la zone $\mathrm{H}$ d'inventaire forestier située près de Prince George en Colombie-Britannique, au moyen d'un échantillonnage effectué le long des routes et du mesurage des arbres matures infectés. Les effets du faux-gui sur le dhp sont évidents seulement dans deux des sous-régions étudiées (Westlake et Nechako). Après correction des mesures du dhp selon la compétition (densité du peuplement), le dhp des arbres de 100-120 ans et de $121-150$ ans a été réduit de $10 \%$ et de $17 \%$ pour chaque classe respectivement, pour la catégorie à plus haut indice de faux-gui (DMR) (4.5-6.0). Les relations entre la hauteur et le dhp étaient perturbées par le faux-gui seulement dans la région de Nechako. Les effets du faux-gui dans les régions de Nechako et de Westlake pour les peuplements de plus de 120 ans ayant un indice de faux-gui de 4.5-6.0, entraînaient des réductions de volume de 28 à $42 \%$, selon les effets du faux-gui sur la hauteur. D'autres pertes pourraient être occasionnées dans les peuplements de pin lodgepole advenant que les coupes à blanc soient restreintes par le Code de pratique forestière de la C.-B., à moins que les tiges infectées ne fassent l'objet d'une coupe de jardinage.

Mot clés: échantillonnage le long des routes, indice de faux-gui, Code de pratique forestière

\section{Introduction}

Dwarf mistletoe (Arceuthobium americanum Nutt. ex Engelm.) is a widespread, damaging parasite of lodgepole pine (Pinus contorta Dougl. var. latifolia Engelm.) (van der Kamp and Hawksworth 1984; Hawksworth and Johnson 1989). Dwarf mistletoe spreads by explosive discharge of the seeds, which are sticky and are intercepted by needles and twigs. The seeds slide down the needles during rain and adhere tightly to the twigs. When the seed germinates, the radicle produces a holdfast, and penetrates the cortex and xylem of the host. After two to three years, a swelling becomes visible and enlarges as aerial shoots of the mistletoe appear, producing flowers and seeds which repeat the cycle. Infections are perennial and result in dense, abnormally branching brooms. Heavily infected trees show a decline in growth, ending in mortality (Hawksworth and Johnson 1989; Hawksworth and Wiens 1996).

Effects of mistletoe on tree growth have been studied by stem analysis methods, through comparisons of trees from healthy and affected plots (Baranyay and Safranyik 1970; Thomson and Smith 1983; Thomson et al. 1984, 1985). However, mistletoe spreads more rapidly in open stands, where inter-tree competition would be relatively low, than in closed stands where com-

\footnotetext{
'Pacific Forestry Centre, 506 West Burnside Road, Victoria, British Columbia, Canada V8Z $1 \mathrm{M} 5$.

${ }^{2} \mathrm{BC}$ Ministry of Forests, Silviculture Branch, 31 Bastion Square, Victoria, British Columbia, Canada V8W 3E7.

${ }^{3}$ University of Northem British Columbia, 3333 University Way, Prince George, British Columbia, Canada V2N 4Z9.
}

petition would be high (Parmeter 1978); thus, mistletoe effects must be separated from effects of competition (stand density) on growth (Thomson and Smith 1983; Thomson et al. 1985). This is especially true for lodgepole pine (Pinus contorta Dougl. var. latifolia Engelm.), where highly variable withinstand stem density (Smithers 1961; Johnstone 1976; Thomson 1987) can result in low density (low competition) trees with dwarf mistletoe having a larger mean diameter than healthy trees from higher density parts of the same stand.

Evaluation of regional impacts of a disease requires knowledge of the distribution and severity of infections, and also the impact of a particular infection severity on the growth of trees and stands. Roadside surveys have been used to determine spatial pattern and incidence for dwarf mistletoe (Hawksworth 1958; Drummond 1978; Van Sickle and Smith 1978; Johnston et al. 1979), as well as a number of other diseases: comandra blister rust (Andrews and Harrison 1959), and white pine blister rust (Brown 1978). Lundquist (1993) used the method for a number of diseases as well as for patch mortality from an unknown cause. A much more intensive sampling procedure is required for detailed epidemiological studies (Alfaro et al. 1985).

The purpose of the present study was to determine the regional impact of dwarf mistletoe near Prince George, British Columbia, by (1) determining the reduction in tree volume associated with a given lodgepole pine dwarf mistletoe rating (DMR), (2) determining the proportion of the forest having each DMR through a roadside survey and inventory plots, and (3) determining volume correction factors for mistletoe in the surveyed area. 


\section{Methods}

Effects of mistletoe on diameter at $1.43 \mathrm{~m}(\mathrm{DBH})$ were determined in eight stands of lodgepole pine sampled near Prince George, British Columbia. All stands were even-aged and pure or nearly pure (i.e. $80 \%$ or more by stems ha ${ }^{-1}$ ) lodgepole pine. In each stand, four 0.01 ha circular plots were established, covering a range of DMRs, for a total 32 plots. Twelve plots were located in stands of age 101-120 years, while the remaining 20 were in stands age $121-160$. For each tree within each plot, DBH was measured and DMR estimated using the sixclass system of Hawksworth (1977). Hawksworth and Wiens (1996) indicate that reduction of lodgepole pine growth does not occur until the DMR exceeds 3.0, thus for all analyses, DMR ratings of 0.0-3.0 were grouped together as "healthy".

Tree age was determined from increment cores at breast height. The heights of the three tallest trees in each plot were measured. Site index for each stand was determined from top height and age (Johnstone 1976; Thomson 1987), assuming no effect of mistletoe on height. The average of the top heights from all four plots in the stand was used to determine site index of the stand. From this site index and corresponding tree age, an expected stem density and corresponding average $\mathrm{DBH}$ were obtained. A correction factor for $\mathrm{DBH}$ as a function of deviations from this expected density in healthy stands was determined from the equations of Johnstone (1976) and Thomson (1987). This correction factor was then applied to the observed DBH values in the plots, based on the stem density in the plot.

The roadside survey for dwarf mistletoe was conducted in 1986 in six sub-regional areas within or bordering B.C. Forest Inventory Zone H (Fig. 1), near Prince George, British Columbia. The extent of the survey was constrained by the availability of roads, and varied with area (Table 1).

Mistletoe incidence was estimated (Johnston et al. 1979) on both sides of the road every $0.1 \mathrm{~km}$. An incidence of 0 indicated no infection, 1 indicated from $1-33 \%$ of stems infected, 2 indicated $34-66 \%$ infected, and 3 indicated $67-100 \%$ of stems infected. At $5.0 \mathrm{~km}$ intervals, a standard BCFS inventory plot was established $50 \mathrm{~m}$ within the stand and DBH and DMR determined for all trees. Height was measured on three trees for each plot. At Nechako, $74 \%$ of these trees had no mistletoe, while of the infected trees, $65 \%$ had DMR $<4$. At Westlake, $36 \%$ of these trees had no mistletoe, while of the infected trees, $60 \%$ had DMR $<4$.

Stem volume of the trees on which both $\mathrm{DBH}$ and height were measured was determined from taper equations (BC Ministry of Forests Inventory Branch). Potential DBH in the absence of dwarf mistletoe, given the tree's age and DMR, was based on averages (Table 2), and used in the taper equations to estimate potential volume (Thomson et al. 1983). Two estimates of potential volume were made, using different assumptions about the effects of DMR on height growth; a) no effect of DMR on height growth, and b) height growth reduced by the same percentage as DBH. Volume losses were then estimated by comparison of actual and potential volumes for the plots of the Westlake and Nechako areas, the only areas with a high enough incidence of dwarf mistletoe to exhibit detectable losses with this impact assessment technique.

\section{Results}

\section{Effects of Mistletoe on DBH}

Effects of DMR on average diameter varied with age (Table 2). Diameter at breast height was reduced by up to $17 \%$ in the oldest trees at DMR levels over 4.5.

\section{Effects of Mistletoe on Height and Volume}

Extensive dwarf mistletoe occurred only in the Nechako and Westlake areas (Table 1). Subsequent analyses focused on these two areas. Height and diameter measurements of the trees in the roadside survey plots were used to construct height/DBH curves. Healthy trees from all areas except Westlake and Nechako had similar growth patterns and were combined in one group. In the Westlake and Nechako areas, trees with DMRs of 0 to 3 were combined in one group, while trees with DMRs of 4 to 6 were combined in a second group (Table 3, Fig. 2).

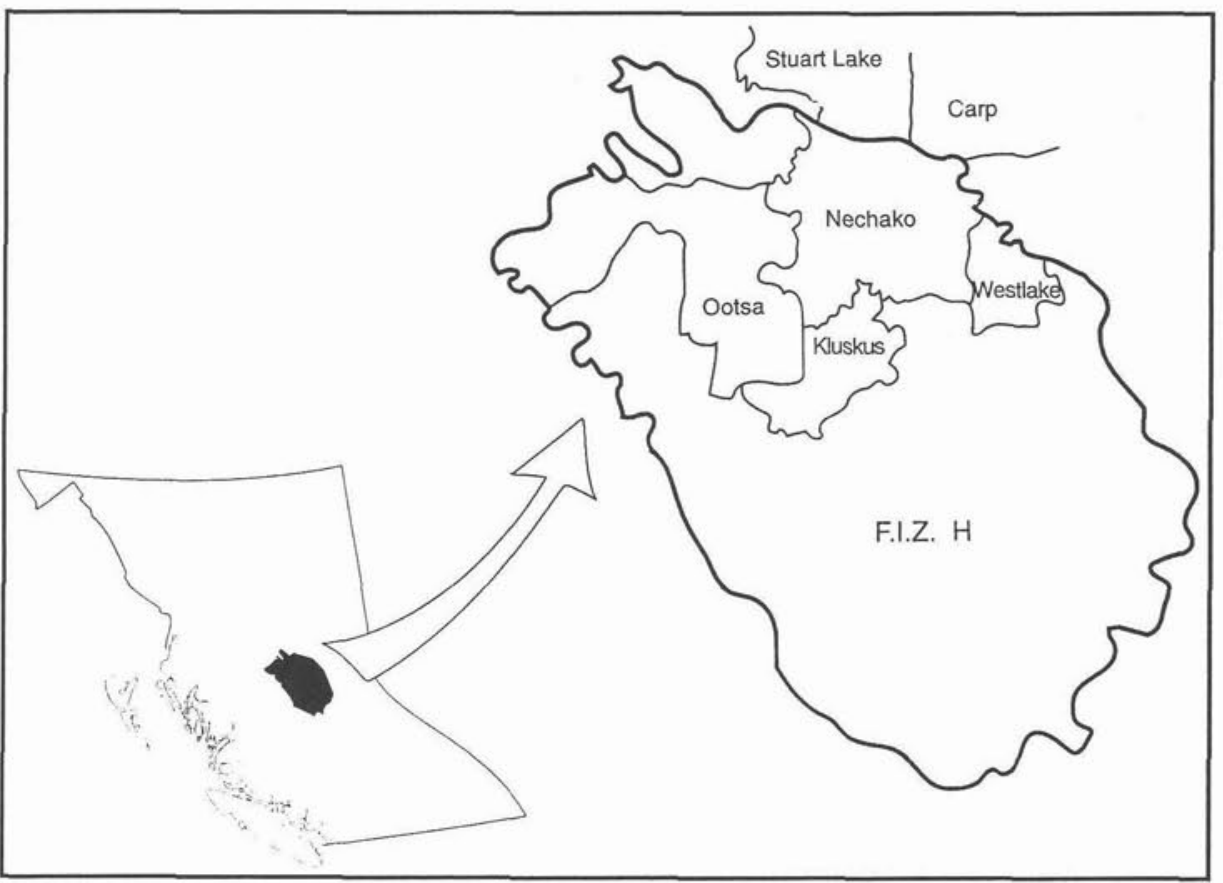

Fig. 1. The six sub-regions studied (thin lines), in relation to the boundary of Forest Inventory Zone H (thick line). 
Table 1. Summary of dwarf mistletoe roadside survey results for each area, indicating total road length $(\mathrm{km})$ surveyed and the percentage of the survey by dwarf mistletoe incidence level

\begin{tabular}{lccccc}
\hline & \multirow{2}{*}{$\begin{array}{c}\text { Length } \\
\text { Area }\end{array}$} & \multicolumn{4}{c}{ Dwarf mistletoe incidence level } \\
\cline { 3 - 6 } & $\mathbf{( k m )}$ & $\mathbf{0}$ & $\mathbf{1 - 3 3 \%}$ & $\mathbf{3 4 - 6 6 \%}$ & $\mathbf{5 6 7 \%}$ \\
\hline Carp & 120 & 84 & 11 & 3 & 1 \\
Kluskus & 58 & 72 & 10 & 6 & 13 \\
Nechako & 311 & 52 & 20 & 14 & 14 \\
Ootsa & 32 & 85 & 9 & 3 & 3 \\
Stuart & 159 & 91 & 7 & 1 & 0 \\
Westlake & 123 & 12 & 16 & 30 & 41 \\
\hline
\end{tabular}

Table 2. Effects of dwarf mistletoe rating (DMR) and stand age on average plot dbh, corrected for stem density effects and expressed as percent of the expected DBH. The average, range and number of plots $(N)$ in each category is given

\begin{tabular}{lccccccc}
\hline & \multicolumn{6}{c}{ \% of expected DBH } \\
\cline { 2 - 4 } \cline { 6 - 8 } DMR & \multicolumn{3}{c}{ Age 101-120 } & & \multicolumn{3}{c}{ Age 121-150 } \\
\cline { 2 - 4 } \cline { 6 - 8 } & Average & Range & $\mathbf{N}$ & & Average & Range & N \\
\hline$<3.0$ & - & - & - & & 98 & $95-100$ & 3 \\
$3.0-4.5$ & 94 & $92-102$ & 6 & & 88 & $81-99$ & 10 \\
$>4.5$ & 91 & $90-94$ & 6 & & 83 & $75-95$ & 7 \\
\hline
\end{tabular}

Healthy trees from the Nechako and Westlake areas had a lower height for a given $\mathrm{DBH}$ than the healthy trees in the other areas. High mistletoe ratings resulted in a slight reduction on the height/DBH relationship at Westlake, and a more pronounced reduction at Nechako.

Volume losses for the plots of the Westlake and Nechako areas were estimated by comparison of actual and potential volumes (Table 4). In the oldest age group, volume losses up to $30-40 \%$ at high DMRs were estimated, depending on whether or not the mistletoe was assumed to have an effect on height. These estimates are comparable to the $25-35 \%$ losses reported in Van Sickle and Smith (1978).

\section{Distribution of DMR Levels and Volume Correction Factors}

Standard inventory plots which were established every $5.0 \mathrm{~km}$ along the road network were used to relate DMR to roadside infestation level (Table 5). Average plot DMR values of 4.5 and above were found only at the highest roadside rating. In the Nechako area for example, $11.1 \%$ of the plots associated with roadside ratings of 3 (> $66 \%$ of stems infected) had DMR levels over 4.5 , whereas in the Westlake area, only $7.1 \%$ of such plots had DMR levels over 4.5 .

Applying percentages (Table 5) to the survey roadside ratings (Table 1) in the Nechako area, $94.5 \%$ of the lodgepole pine area had DMR $<3.0,3.9 \%$ of the area had DMR in the range $3.0-4.5$, and $1.5 \%$ of the area had DMR $>4.5$. The corresponding percentages for Westlake were $80.4,16.6$, and $2.9 \%$.

Volume correction factors $(\mathrm{CF})$ for the Nechako and Westlake areas were then determined, as described below, by combining infestation percentages with volume reductions (Table 4). For a conservative estimate, we assumed that there was no growth loss where DMR was less than 3.0, as indicated by Hawksworth and Wiens (1996). Using an average of the two hypotheses regarding height effects (Table 4), DMR values of $3.0-4.5$ resulted in $13 \%$ reduction in volume of $101-120$ year old trees, and $21 \%$ reduction in volume of trees older than 120 .
Similarly, DMR values $>4.5$ resulted in $27 \%$ reduction in volume of 101-120 year old trees, and $35 \%$ reduction in volume of trees older than 120 .

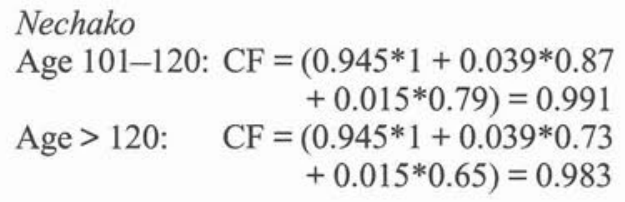

Westlake

Age 101-120: $\mathrm{CF}=(0.804 * 1+0.166 * 0.87$ $+0.029 * 0.79)=0.971$

Age $>120: \quad \mathrm{CF}=(0.804 * 1+0.166 * 0.73$

$$
+0.029 * 0.65)=0.944
$$

\section{Discussion}

Losses due to dwarf mistletoe have been reported as being most closely related to time since infection, and to a lesser extent to stand age at the time of infection (Hawksworth and Hinds 1964). However, as these times and ages are generally unknown, losses are more usually related to present mistletoe ratings. In the present study, after correcting growth for competition (stand density) effects, reductions in DBH with dwarf mistletoe were found to be related to tree age and dwarf mistletoe rating. Mistletoe effects were evident only on trees with high dwarf mistletoe ratings (DMR > 3), as indicated in other studies (Hawksworth and Wiens 1996). Reduction in DBH was most evident in the oldest trees (Table 2). Given that reduction in DBH of stands older than 100 amounted to only $6 \%$ (Table 2 ), growth impacts in younger stands may be difficult to detect.

Mistletoe effects on height were evaluated through comparison of height/DBH relationships. The height/DBH curve was reduced at high mistletoe ratings only in the Nechako area. Estimates of volume reduction depend on whether or not height was reduced, thus estimates were provided under both assumptions. The loss estimates of the present study may be low, as volume losses were computed from a taper equation assuming no effect of mistletoe on form. However, mistletoe effects on growth may be more pronounced higher in the crown than they are on DBH (Baranyay and Safranyik 1970), which would result in greater loss than predicted.

For effects of dwarf mistletoe to be significant in an area, three criteria must be met: (1) many stands must have mistletoe present; (2) the mistletoe must occur through most of the stand area rather than in small centres, and (3) the level of infection of the trees in the stands must be high. Using a roadside survey, most sub-regions of the surveyed area had both a low incidence of mistletoe and relatively low levels of infection in those parts where it did occur. In only two sub-regions (Westlake and Nechako) were all three criteria met.

The fact that the height/DBH curves for healthy trees in the Nechako and Westlake areas were different from the curve for healthy trees in the other areas within the BC Forest Inventory Zone $\mathrm{H}$ may be due to differences in site in these areas. Site differences have been reported to have a major effect on mistletoe impact, and are not well understood. For example, “... vigorous lodgepole pines are more liable to damage. Statements regarding the effects of host vigor on mistletoe development are not apt to have much significance unless the stand and site characteristics are specified. While a vigorous tree in 
Table 3. Parameters for the regression equations for the curves in Fig. 2, of the form $y=a+b^{*} \ln (x)+c^{*} x$, where $y$ is tree height (m), and $x$ is DBH $(\mathrm{cm})$. The healthy category includes the Carp, Kluskus, Ootsa and Stuart areas, while the data from the Nechako and Westlake areas was partitioned on the basis of the dwarf mistletoe rating (DMR)

\begin{tabular}{|c|c|c|c|c|c|c|c|}
\hline \multirow[b]{2}{*}{ Category } & & \multirow[b]{2}{*}{ Curve } & \multirow[b]{2}{*}{$N$} & \multirow[b]{2}{*}{$R^{2}$} & \multicolumn{3}{|c|}{ Parameters } \\
\hline & & & & & $a$ & $b$ & $c$ \\
\hline Healthy & & 1 & 229 & 0.796 & -14.01 & 10.87 & 0.13 \\
\hline Westlake & (DMR 0-3) & $2 a$ & 84 & 0.759 & -10.14 & 10.42 & 0.03 \\
\hline Westlake & (DMR $4-6)$ & $2 b$ & 29 & 0.591 & 8.06 & 2.39 & 0.30 \\
\hline Nechako & (DMR 0-3) & $3 a$ & 206 & 0.679 & -12.25 & 10.85 & -0.01 \\
\hline Nechako & (DMR $4-6$ ) & $3 b$ & 34 & 0.447 & -0.70 & 5.74 & 0.12 \\
\hline
\end{tabular}

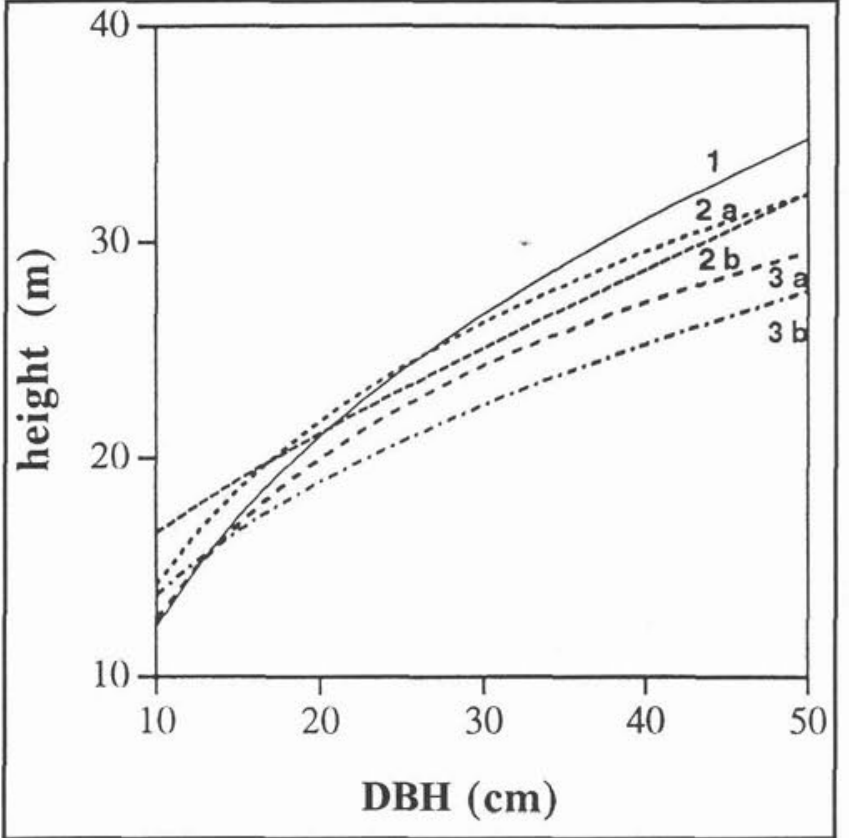

Fig. 2. Height/DBH curves showing the difference of the Westlake $(2 \mathrm{a}, \mathrm{b})$ and Nechako $(3 \mathrm{a}, \mathrm{b})$ areas from the combined Kluskus, Ootsa, Stuart and Carp areas (1). Curves $2 \mathrm{a}$ and $3 \mathrm{a}$ are for trees with DMR values of $0-3$, while $2 b$ and $3 b$ are for DMR values $4-6$.

one stand may be more liable to damage, a similar tree in another stand may be less liable to damage" (Parmeter 1978). In addition, "[s]imilar densities on high and low sites may not have similar effects on dwarf mistletoes" (Parmeter 1978). Both the Westlake and Nechako areas are drier than the other parts of the region, and mistletoes are known to have an effect on the water balance of trees, having a transpiration rate up to 40 times that of the host, on a surface area basis (Tocher et al. 1984). Effects of the mistletoe on tree growth are probably greatest when the trees are stressed.

The approach used in this evaluation of sub-regional impacts illustrates a general approach to damage estimation where different severity indices are involved at different scales of study; i.e. average DMR is used at the plot scale where volume reduction factors are estimated, whereas incidence levels were used for large scale survey. The roadside survey approach is useful for indicating sub-regional differences in impact patterns, but is limited in its ability to generate estimates of total impact, as the sampling is non-random, thus may not reflect the overall forest composition of the area. In addition, the road network may vary in extent of coverage in the different sub-regions.
Table 4. Effects of dwarf mistletoe rating (DMR) and stand age on tree volume (proportion of healthy tree volume). Estimates are provided under two assumptions: (1) height reduced by same proportion as dbh, and (2) no reduction in height. $N$ is the number of plots occurring in each category. The Westlake and Nechako areas were combined in this table

\begin{tabular}{lllccc}
\hline Age & DMR & $\boldsymbol{N}$ & $\begin{array}{c}\text { Height } \\
\text { affected }\end{array}$ & $\begin{array}{c}\text { Height } \\
\text { not affected }\end{array}$ & Average \\
\hline $101-120$ & $>3.0$ & 4 & 1.00 & 1.00 & 1.00 \\
& $3.0-4.5$ & 5 & 0.84 & 0.90 & 0.87 \\
& $>4.5$ & 2 & 0.68 & 0.78 & 0.73 \\
$>120$ & $>3.0$ & 1 & 1.00 & 1.00 & 1.00 \\
& $3.0-4.5$ & 1 & 0.75 & 0.83 & 0.79 \\
& $>4.5$ & 1 & 0.58 & 0.72 & 0.65 \\
\hline
\end{tabular}

Table 5. Percent of plots from each roadside rating, having DMR values of $<3.0,3.0-4.5$, and $>4.5$, for the Westlake and Nechako areas. The number of plots in each class is given in parenthesis

\begin{tabular}{lcrrr}
\hline & Roadside & \multicolumn{4}{c}{$\%$ of plots } \\
\cline { 2 - 5 } Area & Rating & $<\mathbf{3 . 0}$ & $\mathbf{3 . 0 - 4 . 5}$ & $>\mathbf{4 . 5}$ \\
\hline Nechako & 0 & $100(62)$ & $0(0)$ & $0(0)$ \\
& $1-33 \%$ & $100(9)$ & $0(0)$ & $0(0)$ \\
& $34-66 \%$ & $94(15)$ & $6(1)$ & $0(0)$ \\
& $>66 \%$ & $67(12)$ & $22(4)$ & $11(2)$ \\
Westlake & 0 & $100(7)$ & $0(0)$ & $0(0)$ \\
& $1-33 \%$ & $83(5)$ & $17(1)$ & $0(0)$ \\
& $34-66 \%$ & $93(13)$ & $7(1)$ & $0(0)$ \\
& $>66 \%$ & $64(9)$ & $29(4)$ & $7(1)$ \\
\hline
\end{tabular}

In individual stands, where most of the trees are affected and the average infection level is high, volume losses can be large. Clearcut harvesting can eradicate dwarf mistletoe, although reinfection from adjacent infected stands can occur. With smaller cutblocks, the perimeter/area ratio increases, resulting in increased mistletoe problems in the new stand. Pre-commercial and commercial thinning, as well as partial harvesting systems which open up the stand, can create conditions which enhance mistletoe growth and facilitate spread. Thus, new forest management practices under the Forest Practices Code, that restrict sizes of clearcuts and encourage retention of mature trees, might tend to increase the prevalence of mistletoe (B.C. Forest Service 1995), so further increases in the loss estimates can be anticipated, unless infected stems are selectively removed.

\section{Acknowledgments}

We wish to thank Deirdre Caune for her assistance in the data analysis; Industrial Forest Service Ltd. conducting surveys, stem analyses and data analysis, and M.J. Schulting, RPF, for data collection. Drs. G.A. Van Sickle, L. Safranyik and R. Alfaro reviewed the manuscript and provided comments. 


\section{References}

Alfaro, R.I., W.J. Bloomberg, R.B. Smith and A.J. Thomson. 1985. Epidemiology of dwarf mistletoe in western hemlock stands in south coastal British Columbia. Can. J. For. Res. 15: 909-913.

Andrews, E.A. and M.D. Harrison. 1959. Cronartium comandrae in Wyoming. Plant Disease Reporter 43: 418-419.

Baranyay, J.A. and L. Safranyik. 1970. Effect of dwarf mistletoe on growth and mortality in Alberta. Canadian Forestry Service Publication No. 1285.19 p.

BC Forest Service. 1995. Forest Practices Code of British Columbia. Dwarf mistletoe management guidebook. Province of British Columbia, July 1995.20 p.

Brown, D.H. 1978. The status of white pine blister rust on limber pine and whitebark pine in Wyoming. Tech. Report R2-13. Lakewood CO: USDA For. Serv., Forest Insect and Disease Management. 10 p.

Drummond, D.B. 1978. Approaches to determining volume losses due to dwarf mistletoe on a westwide basis. pp. 55-61. In: Proc. Symp. on Dwarf mistletoe control through forest management. R.F. Scharpf and J.R. Parmeter, Jr., eds. USDA Pacific Southwest For. and Range Expt. Sta., Gen. Tech. Rept. PSW-31.

Hawksworth, F.G. 1958. Survey of lodgepole pine dwarf mistletoe on the Roosevelt, Medicine Bow, and Bighorn National Forests. Station Paper No. 35. Fort Collins, CO: USDA For. Serv., Rocky Mountain For. and Range Expt. Sta. 13 p.

Hawksworth, F.G. 1977. The 6-class dwarf mistletoe rating system. USDA For. Serv., Rocky Mountain For. and Range Expt. Sta. Gen. Tech Rept. RM-48. 7 p.

Hawksworth, F.G. and T.E. Hinds. 1964. Effects of dwarf mistletoe on immature lodgepole pine stands in Colorado. J. Forest. 62: 27-32. Hawksworth, F.G. and D.W. Johnson. 1989. Biology and management of dwarf mistletoe in lodgepole pine in the Rocky Mountains. USDA For. Serv. Gen. Tech. Rep. RM-169. 34 p.

Hawksworth, F.G. and D. Wiens. 1996. Dwarf mistletoes: biology, pathology, and systematics. USDA Forest Service, Agricultural Handbook 709. Washington, DC. 410 p.

Johnstone, W.D. 1976. Variable-density yield tables for natural stands of lodgepole pine in Alberta. Can. For. Serv., For. Tech. Rep. No. 20.110 p.

Johnston, D.W., Hawksworth, F.G. and D.B. Drummond. 1979. Dwarf mistletoe loss assessment survey Bighorn and Shoshone National Forests, Wyoming. USDA For. Serv. Report 79-3. 8 p. Available from Methods Applications Group, Davis, CA.
Lundquist, J.E. 1993. Large scale spatial patterns of conifer diseases in the Bighorn Mountains, Wyoming. USDA For. Serv., Rocky Mountain For. and Range Expt. Sta., Res. Note RM-523. 8 p.

Parmeter, J.R., Jr. 1978. Forest stand dynamics and ecological factors in relation to dwarf mistletoe spread, impact, and control. pp. 16-30. In: Proc. Symp. on Dwarf mistletoe control through forest management. R.F. Scharpf and J.R. Parmeter, Jr. eds. USDA Pacific Southwest For. and Range Expt. Sta., Gen. Tech. Rept. PSW-31.

Smithers, L.A. 1961. Lodgepole pine in Alberta. Can. Dep. For. Bull. No. 127.153 p.

Thomson, A.J. 1987. Comparison of lodgepole pine yield tables. Can. J. For. Res. 17: 1110-1114.

Thomson, A.J. and R.B. Smith. 1983. Growth patterns in a young western hemlock plantation infested with dwarf mistletoe. Can. J. For. Res. 13: 972-978.

Thomson, A., R. Smith and R. Alfaro. 1983. Western hemlock growth losses caused by dwarf mistletoe. pp. 21-33. In Proc. Workshop on Management of Hemlock Dwarf Mistletoe (1983, Burnaby, B.C.). J. Muir, ed. BCMF Pest Management Report Number 4.

Thomson, A.J., R.B. Smith and R.I. Alfaro. 1984. Growth patterns in immature and mature western hemlock stands infected with dwarf mistletoe. Can. J. For. Res. 14: 518-522.

Thomson, A.J., R.I. Alfaro, W.J. Bloomberg and R.B. Smith. 1985. Impact of dwarf mistletoe on the growth of western hemlock trees having different patterns of suppression and release. Can. J. For. Res. 15: 665-668.

Tocher, R.D., S.W. Gustafson and D.M. Knutson. 1984. Water metabolism and seedling photosynthesis in dwarf mistletoes. pp. 62-69. In: Proc. Symp. Biology of dwarf mistletoes. F.G. Hawksworth and R.F. Scharpf(Tech. Coordinators). USDA For. Serv. Gen. Tech. Rep. GTR RM-111.

van der Kamp, B. and F.G. Hawksworth. 1984. Damage and control of the major diseases of lodgepole pine. pp. 125-131. Proc. Symp. Lodgepole pine. The species and its management. In: D.M. Baumgartner, R.G. Krebill, J.T. Arnott, and G.F. Weetman, eds. 8-10 May 1984. Spokane, WA; May 14-16; Vancouver, B.C. Pullman, WA, Washington State University.

Van Sickle, G.A. and R.B. Smith. 1978. Dwarf mistletoe controls in British Columbia. pp. 106-112. In: Proc. Symp. on Dwarf mistletoe control through forest management. R.F. Scharpf and J.R. Parmeter, Jr. (eds.). USDA Pacific Southwest For. and Range Expt. Sta., Gen. Tech. Rept. PSW-31. 